\title{
A successful habitat reconstruction effort, the short history of the European Bee-eater (Merops apiaster) colony at Albertirsa (Hungary)
}

\author{
SÁndor Urbán ${ }^{1}$, Katalin TúRI ${ }^{1}, Z_{\text {ZotTÁn VAS }}^{2} \&$ Tibor IstVÁn Fuisz ${ }^{2 *}$
}

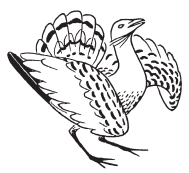

Sándor Urbán, Katalin Túri, Zoltán Vas \& Tibor István Fuisz 2013. A successful habitat reconstruction effort, the short history of the European Bee-eater (Merops apiaster) colony at Albertirsa (Hungary). - Ornis Hungarica 21(2): 47-51. the loess deposited in the last glacial period, offering natural nesting sites for the European Bee-eater. Later the deeply cut coach roads, the pits of loess extraction and the construction works of the motorway nearby created further man-made banks. Hence by the 1970-ies a well-established colony bred here, but by the beginning of the $21^{\text {st }}$ century, disturbance and the demise of vertical banks led to a serious reduction in the number of breeding pairs. The purchase of 5-hectare loess grassland plot and the adjacent loess bank, and later its reconstruction led to an unprecedented growth in the number of Bee-eaters. From 2010 the number of breeding pairs exceeded 200 every year. Not only the Bee-eater colony, but also the natural vegetation and the botanical values of the area are managed to maintain the population of rare and protected element of the local flora and fauna.

Keywords: European Bee-eater, Merops apiaster, habitat reconstruction, conservation biology, nature protection

Összefoglalás Az albertirsai Golyófogó-völgyben a jégkorszakban felhalmozódott löszbe vájt eróziós völgy falai régóta természetes fészkelési lehetőséget biztosítanak a gyurgyalagnak. A falu határában a vályogkészítéshez használt lösz kitermelése után maradt gödrök falai, a bevágódott mélyutak, majd később az autoút építkezés révén további ember alkotta fészkelőhelyek jöttek létre. Ennek köszönhetően az 1970-es évekre a partfalban költő kolónia létszáma megnőtt, de a 21. század elejére a zavarásnak, illetve a falak leomlásának köszönhetően a gyurgyalagok száma alaposan megcsappant. A Golyófogó-völgyben egy öthektáros löszgyep és a hozzátartozó partfal megvásárlása, majd 2009-es rekonstrukciója után a költő párok száma 2010-től 200 pár fölé emelkedett. A gyurgyalag kolónia mellett a terület botanikai értékeinek és természetes növénytársulásainak megörzésére is törekednek a természetvédők, hogy ezzel biztosítsák a helyi állat- és növényvilág ritka és értékes elemeinek megörzését.

Kulcsszavak: gyurgyalag, Merops apiaster, élőhely-rekonstrukció, természetvédelem, természetvédelmi biológia

${ }^{1}$ Jásznagykun Nature Protection Organisation, 5001 Szolnok Pf. 188.

${ }^{2}$ Department of Zoology, Hungarian Natural History Museum, 1088 Budapest, Baross utca. 13., Hungary

*Corresponding author e-mail: tibor.i.fuisz@gmail.com

\section{Introduction}

The European Bee-eater (Merops apiaster Linnaeus, 1758) is the sole representative of its family, Meropidae in Hungary. Although no other member of its family breeds in, or migrates through the
Carpathian Basin, the species itself is far from solitary, or even scarce. According to a recent study at the beginning of the $21^{\text {st }}$ century the European breeding population is estimated 480000 pairs (BirdLife International 2004). It is a gregarious bird characterised by colonial breeding and 
intricate sociality (Cramp 1998). The species is strictly protected in Hungary, and its nature conservation value is 100000 Hungarian Forints. The pairs usually breed in colonies in loess- or sandbanks, and the number of pairs can range from a handful to several hundred. The active hole drilling - sometimes the length of the tunnel to the breeding chamber exceeds 2 metres (Bankovics 1998) - helps to turn over the soil, and hence the Bee-eaters is considered an ecosystem engineer species (Casas-Crivillé 2005, Sekercioglu 2006). Besides turning over the soil and hence contributing to its mixing and providing more oxygen the excavated tunnels might give breeding opportunities to other bird species also. We observed, captured and ringed the following hole nesting species breeding in the bank: Common Starling (Sturnus vulgaris), Tree Sparrow (Passer montanus) and Sand Martin (Riparia riparia). Hoopoes (Upupa epops) were also often observed flying around the bank and searching for insects on the loess wall itself, but we did not find an actual Hoopoe nest in the wall.

The number of breeding pairs in Hungary was estimated between 1000-3000 pairs at the beginning of the 1990-ies (Bankovics 1998, 2000), and its population has been slowly increasing since the 1970-ies (Magyar et al. 1998, Hadarics \& Zalai 2008). Gyurácz et al. (2013) estimates, based on extrapolations of the censuses carried out lately in Hungary that the breeding population is around 20000-30000 pairs.

According to the surveys of the colonies in Hungary during the $20^{\text {th }}$ century $90 \%$ of the European Bee-eater population breeds in colonies counting less than 50 individuals. Although Szijj (1955), who compiled the data from the 1949 census on the species, mentioned a colony counting 400 individuals from the vicinity of Simontornya, based on the observation of Dániel Kerekes. Szijj established that 55 (93.22\%) of the observed 59 colonies contained less than 80 pairs, only 3 colonies counted between $80-100$, and one colony above 100 breeding pairs. The situation remained similar during the second half of the $20^{\text {th }}$ century, the majority of colonies were used by less than 50 breeding pairs (Nagy et al. 2008). From 2010 the Albertirsa colony hosts over 200 breeding pairs, so the loess wall itself and the surrounding habitats offer an exceptional nesting site and reliable food source. Colonial nesting in the European Bee-eater is a well-known phenomenon, but from solitary breeding to forming large colonies a whole continuum is reported in the species. Interestingly Hoi et al. (2002) reported that colony size had a negative effect on chick condition and survival. It is thought that adult survival might be still better in larger colonies, and hence lifetime reproductive success is higher for birds breeding in larger colonies.

As this species requires almost vertical, vegetation-free walls for breeding, the main threat to the species is the loss of breeding sites. Disturbance of breeding colonies (such as mining activities at the banks in the breeding period) is especially harmful. Other threatening factors for this species include persecution from beekeepers involving shooting, poisoning and intentional blocking of breeding hole entrances (Bankovics 2000, Gyurácz 2009). As many colonies are established in sand and loess excavation sites, human interference is an important threatening factor, just like the natural re-growth of vegetation in abandoned excavation sites. 


\section{The history of the Albertirsa Bee-eater colony}

Albertirsa town lies in the wide valley of the Gerje Stream, and is situated where the undulating Gödöllő Hills meets the Great Hungarian Plain. Loess and sand deposition in the last glacial period created a 10 20 meters thick layer, later eroded by frost and precipitation, and it provided natural breeding sites for the European Bee-eaters. Human loess and clay excavation for construction beginning in the $18^{\text {th }}$ century created a long bank in the Golyófogó Valley east of the village, which gave even more opportunities for breeding. Also, the dirt roads used by coaches and heavy carts cut deeply into the loess, and their walls provided breeding sites for this species. The bank was further excavated when Road Number 4 was built in the 1960-70-ies. The large excavation area left behind created a suitable breeding area for the Bee-

\begin{tabular}{|c|c|}
\hline Year / Év & $\begin{array}{c}\text { Number of pairs } \\
\text { Párok száma }\end{array}$ \\
\hline 2003 & $35-40$ \\
\hline 2004 & $32-37$ \\
\hline 2005 & $30-35$ \\
\hline 2006 & $37-40$ \\
\hline 2007 & $33-35$ \\
\hline 2008 & $39-43$ \\
\hline 2009 & $53-55$ \\
\hline 2010 & $198-202$ \\
\hline 2011 & $258-260$ \\
\hline 2012 & $294-300$ \\
\hline 2013 & 267 \\
\hline
\end{tabular}

Table 1. The number of European Bee-eaters nesting at the colony in the Golyófogó Valley between 2003-2013.

1.táblázat Az albertirsai Golyófogó-völgyben található telepen költő gyurgyalagpárok száma 2003-2013 között eaters, and the number of breeding pairs rose to $150-180$ pairs in the 1970-ies and 1980-ies. The Jászkun Természetvédelmi Szervezet (Jászkun Nature Protection Organisation) started to monitor the breeding of Bee-eaters in the Golyófogó Valley in the 1970-ies. As the area was used as a communal waste deposition till recently, this activity adversely affected the breeding colony. Hence by the beginning of the 1980 -ies the colony numbered around 100 pairs. In the worst period (1986-1987) 2035 pairs bred at the colony. In the 1990-ies the population grew again, and the number of breeding pairs rose to 150-180 between 1999-1997. Due to disturbance and natural erosion of the banks and re-growth of the vegetation lead to a serious decline, by the beginning of the $21^{\text {st }}$ century only 30 40 pairs bred at this colony (Table 1).

On the $26^{\text {th }}$ September 2003 the Jászkun Természetvédelmi Szervezet (Jászkun Nature Protection Organisation) succeeded to buy the whole bank and the adjacent areas (2.89 hectares of arable fields, 1.98 hectares of grassland, 0.3 hectares of soil excavation area) with the financial help of German nature conservation funds. Their aim was to provide protection for the Beeeater colony and also to preserve the original loess grassland vegetation.

In April 2009 the whole bank was reshaped with excavators, and a mostly south-facing 320-meter-long wall was created. Average height is 5 meters, and the maximal height is 11 meters. As a consequence the number of breeding pairs immediately started to rise (Table 1). To further improve the colony's attractiveness to Bee-eaters 5-8 meter high Locust-tree (Robinia pseudoacacia) stumps were erected at about 5 meters from the wall, for the entire length of the artificially improved 
bank. These provide suitable observation posts for the sit-and-wait style hunts, and provide substrate for rest and socialising.

To enhance the re-growth of loess steppe vegetation around the loess bank, and hence create diverse vegetation for insects, the leaf litter was removed from a large tract of the area, and the number of Hart's Milk Vetch (Astragalus exscapus) rose from the earlier $600-1000$ to 2820 in 2012. Besides European Bee-eaters several other valuable species used the loess bank for breeding. Before the 2009 restoration two Common Kestrel (Falco tinnunculus) pairs and a Little Owl (Athene noctua) used to breed in the bank. After the reconstruction of the bank these species disappeared, but in the fall of 2013 several larger cavities will be formed in the wall in the hope that it will help re-establish these birds in the area.

The concerted efforts of (1) creating an enormous suitable loess wall, (2) maintained through the years to control vegetation growth and prevent abrasion of the wall, coupled with (3) creating natural vegetation to provide diverse food source, and (4) the installation of dry trees in front of the nest-holes for the breeding birds to create a platform for hunting, lookout for prey and socialize created ideal breeding conditions for the European Bee-eater. The number of nesting pairs in the later years approximate 300 , and this is the largest known colony in Hungary, and possibly in Central-Europe.

Also while there was a strong European Rabbit (Oryctolagus cuniculus) population the otherwise rare Wildcat (Felis silvestris) was regularly seen in the Golyófogó Valley. Since the rabbit population was wiped out from the area by myxomatosis the Wildcat also disappeared from here.
The case of the Albertirsa breeding colony proves that serious efforts of local nature conservation organisations are needed to safeguard the populations of even strictly protected species. In the case of species limited by breeding sites first the protection of natural breeding sites, and second the creation and wise management of artificial breeding sites is the only way of increasing the number of breeding pairs. An outstanding example of habitat restoration carried out by the Jászkun Nature Protection Organisation allowed the formation of the largest colony in Hungary for the bird of the year 2013, the European Bee-eater.

\section{Acknowledgements}

The financial help of the Reutlingen group of NABU - secured and provided by Hans Joachim Riedinger and Roland Herdtfelder presidents was crucial for the preservation of this colony. Their financial support enabled the local activists to buy this area. The authors would like to thank the dedicated work in the preservation of the Bee-eater colony and its natural resources for the following persons: Csaba Bálint, Attila Drozd, Ferenc Oláh, Csaba Pálinkás, András Pélyi, György Schvarczinger, Viktor Telepóczki, Péter Urbán, Zoltán Uri Szabó, Vilmos Végvári. Without their help the colony and its habitat would be more vulnerable. János Pásztor and Péter Petró greatly contributed to the census of the breeding pairs. The financial background of our work was provided by the "Zöld Forrás" fund, grant number K-36-09-00261W. The Duna Ipoly National Park Directorate and Tibor Vincze park ranger cordially helped our nature protection efforts. 


\section{References}

Bankovics, A. 1998. Gyurgyalag Merops apiaster (European Bee-eater) - In: Haraszthy, L. (ed.) Magyarország madarai [The birds of Hungary]. Mezőgazda Kiadó, Budapest (in Hungarian)

Bankovics, A. 2000. Gyurgyalag Merops apiaster (European Bee-eater). - In: Haraszthy, L. (szerk.) Magyarország madarai [The birds of Hungary]. 2. javított kiadás. - Mezőgazda Kiadó, Budapest (in Hungarian) pp. 232-233.

BirdLife International 2004. Birds in Europe: population estimates, trends and conservation status. Cambridge, UK: BirdLife International. (BirdLife Conservation Series No. 12.)

Casas-Crivillé, A. \& Valera, F. 2005. The European Bee-eater (Merops apiaster) as an ecosystem engineer in arid environments. - Journal of Arid Environments 60: 227-238. doi:10.1016/j.jaridenv.2004.03.012

Cramp, S. 1998. The complete birds of the Western Palearctic. - CD-ROM. Oxford University Press, Incorporated, Oxford

Gyurácz, J. 2009. Gyurgyalag Merops apiaster Linnaeus, 1758. (European Bee-eater) - In: Csörgö, T., Karcza, Zs., Halmos, G., Magyar, G., Gyurácz, J., Szép, T., Schmidt, A. \& Schmidt, E. (eds.) Magyar madárvonulási atlasz [Hungarian Bird Migration Atlas] - Kossuth Kiadó, Budapest (in Hungarian with English Summary) pp. 37-38.

Gyurácz, J., Nagy, K., Bagdi, A., Hadarics, T. \& Ragats, Zs. 2004. A gyurgyalag (Merops apiaster) monitorozása és védelmi helyzete Magyarországon 1997-2001. [Protection status and monitoring of the Bee-eater (Merops apiaster) in Hungary]. Természetvédelmi Közlemények 11: 481-489. (in Hungarian with English Summary)
Gyurácz, J., Nagy, K., Fuisz, T. I., Karcza, Zs. \& Szép, T. 2013. European Bee-eater (Merops apiaster Linnaeus, 1758) in Hungary: a review. - Ornis Hungarica 21(2): 1-22.

Hoi, H., Hoi, C. Kristofik, J. \& Darolova, A. 2002. Reproductive success decreases with colony size in the European Bee-eater. - Ethology Ecology \& Evolution. 14(2): 99-110. doi:10.1080/08927014. 2002.9522749

Hadarics, T. \& Zalai, T. (eds.) 2008. Nomenclator Avium Hungariae - An annotated list of the birds of Hungary. - MME, Budapest (in Hungarian with English Summary)

Magyar, G., Hadarics, T., Waliczky, Z., Schmidt, A., Nagy, T. \& Bankovics, A. 1998. Nomenclator Avium Hungariae Magyarország madarainak névjegyzéke [An annotated list of the birds of Hungary]. - KTM Természetvédelmi Hivatal Madártani Intézete, Magyar Madártani és Természetvédelmi Egyesület, Winter Fair, Budapest-Szeged (in Hungarian with English Summary)

Nagy, K., Szép, T., Bagdi, A. \& Gyurácz, J. 2008. A gyurgyalag (Merops apiaster) fészkelő állományának helyzete Magyarországon (1997-2003) [The state of the breeding population of the European Bee-eater in Hungary]. - MME 6. Tudományos Ülése. mme-monitoring.hu/php/dl.php?drid=1443. Letöltve: 2013.04.30.

Sekercioglu, C. H. 2006. Increasing awareness of avian ecological function. - Trends in Ecology and Evolution 21(8): 464-471. http://dx.doi. org/10.1016/j.tree.2006.05.007

Szijj, J. 1955. A gyurgyalag 1949. évi fészkelö telepei hazánkban [The Colonies of the Bee-Eater in Hungary in the Year of 1949]. - Aquila 59-62: 185-190. (in Hungarian with English Summary)

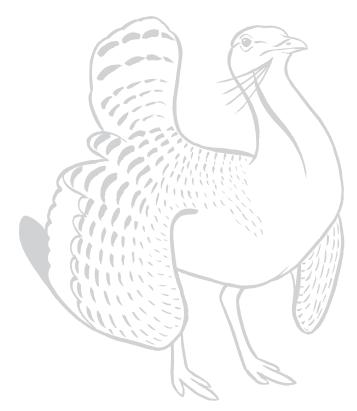

